\title{
Innovating Ireland
}

Last update: 3 March 2020

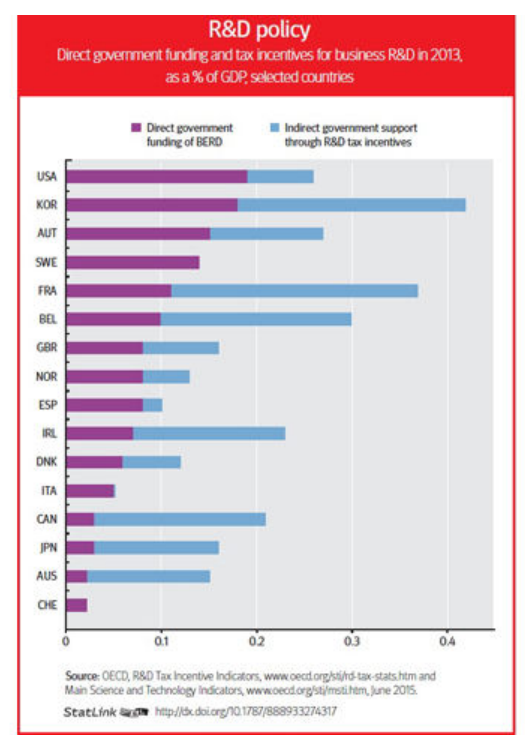

http://dx.doi.org/10.1787/888933274317

Ireland has well-known firms such as Guinness for beer and beverages, Ryanair for air travel, and Smurfit Kappa for paper and packaging, not to mention dairies, beef and fish. However, for a small country that has turned itself into a thriving pharmaceutical and IT hub, Ireland is not awash with global brands in these sectors. Compare with, say, Finland which has Nokia, or Sweden which has Ericsson. True, there is Airtricity, but that innovative wind energy firm now belongs to an overseas company.

And according to a post on LinkedIn's Pulse by Christopher Jimeson, a business consultant, Ireland is building a reputation in precision engineering in the aviation industry, such as Eirecomposites, Schivo Group (originally Waterford Tool Company) and DPF Engineering.

But in general, the Irish $R \& D$ and innovation system, while not a complete laggard (see chart), should be further up the field. Encouraging more spill-overs into the Irish economy would likely improve productivity, create more and better jobs, and support broad socioeconomic development across Ireland (see article by David Haugh).

As with many OECD countries, productivity growth in Ireland has been falling for some time. Although Ireland's multinational sector thrived through the crisis, the domestic small- and medium-sized enteprises (SME) sector has seen relatively 
low levels of competitiveness, productivity and R\&D spending. Strengthening the performance of domestic firms will help rebalance the Irish economy, generate new sources of growth and jobs, and further enhance the country's attractiveness for foreign direct investment (FDI).

This means focusing on the business environment for young, innovative firms, ensuring that innovation programmes have sufficient scale to be efficient and improving the balance between indirect support for business innovation-through $R \& D$ tax incentives-and direct support, which is better suited to these firms.

The government could help strengthen Ireland's domestic sector by shifting the balance away from tax credits and towards more direct support for innovation. R\&D tax credits accounted for some 70\% of all government supports in 2013. Though well designed and efficient in supporting business R\&D in general, cashstrapped smaller firms derive little benefit from them. Direct support-contracts, grants and awards for mission-oriented R\&D, etc-can complement existing tax incentives and can direct public funding to areas of high social and economic returns. It can also help address specific barriers in the Irish innovation system, such as boosting science-industry co-operation.

Moreover, Ireland has relatively few young patenting firms and young firms do not scale very well in many OECD countries, limiting their contribution to innovation, growth and jobs. Policy makers should therefore carefully assess whether any policies inadvertently constrain the growth of such firms. These may include reducing barriers to entrepreneurship as well as access to public procurement. Support for business accelerators and incubators, and better access to research and technology are particularly valuable for young firms and SMEs, and Enterprise Ireland's new Technology Centres can help in this regard.

Policies that strengthen the digital economy also help, and the National Digital Strategy rightly emphasises the importance of digital technologies for Ireland. Improving uptake of fixed broadband connections, which is below the OECD average, and for mobile broadband, which is slightly above it, would act as a boon for small innovative businesses as they reach out to global firms at home as well as to markets in the euro area and beyond.

For more on innovation, contact Dirk.Pilat@oecd.org

\section{References}

Jimeson, Christopher (2015), "Irish aerospace industry at the Salon du Bourget, Hall 4 A4", LinkedIn Pulse, May https://www.linkedin.com/pulse/lindustrie-a \%C3\%A9ronautique-irlandaise-hall-4-a4-au-salon-jimeson?trk=prof-post

"Improving SMEs' access to finance to boost growth and job creation in Ireland", Ireland Policy Brief, OECD Better Policies Series, OECD Publishing, September http://www.oecd.org/policy-briefs/ireland-improving-SMEs-access-tofinance.pdf 
OECD (2015) "Better innovation policies for better lives", Ireland Policy Brief, OECD Better Policies Series, OECD Publishing, September http://www.oecd.org/ policy-briefs/ireland-better-innovation-policies-for-better-lives.pdf

OECD Digital Economy Outlook 2015 http://dx.doi.org/10.1787/9789264232440$\underline{\text { en }}$

The Innovation Imperative http://dx.doi.org/10.1787/9789264239814-en 